\title{
OPEN Dual electrochemical sensing of spiked virus and SARS-CoV-2 using natural bed-receptor (MV-gal1)
}

\author{
E. Ghazizadeh ${ }^{1,2 \bowtie}$, Ali Neshastehriz², Ali Dehghani Firoozabadi ${ }^{3}$, Mohammad Kaji Yazdi $^{4}$, \\ Esmail Saievar-Iranizad ${ }^{5}$ \& Samira Einali ${ }^{2}$
}

It has been necessary to use methods that can detect the specificity of a virus during virus screening. In this study, we use a dual platform to identify any spiked virus and specific SARS-CoV-2 antigen, sequentially. We introduce a natural bed-receptor surface as Microparticle Vesicle-Galactins1 (MV-gal1) with the ability of glycan binding to screen every spiked virus. MV are the native vesicles which may have the gal-1 receptor. Gal-1 is the one of lectin receptor which can bind to glycan. After dropping the MV-gal1 on the SCPE/GNP, the sensor is turned on due to the increased electrochemical exchange with $\left[\mathrm{Fe}(\mathrm{CN})_{6}\right]^{-3 /-4}$ probe. Dropping the viral particles of SARS-CoV-2 cause to turn off the sensor with covering the sugar bond (early screening). Then, with the addition of Au/Antibody-SARS-CoV-2 on the MV-gal1@SARS-CoV-2 Antigen, the sensor is turned on again due to the electrochemical amplifier of AuNP (specific detection). For the first time, our sensor has the capacity of screening of any spike virus, and the specific detection of COVID-19 (LOD: $4.57 \times 10^{2}$ copies $/ \mathrm{mL}$ ) by using the natural bed-receptor and a specific antibody in the point of care test.

SARS-CoV-2 caused the coronavirus epidemic 2019 (COVID-19), which originated in Wuhan, China ${ }^{1}$. The virus has spread epidemically in other countries, killing many people ${ }^{2,3}$. Early and timely diagnosis of this disease is also essential ${ }^{4}$. Rapid antigen tests are the more tests used to identify COVID-19 due to their high speed and low cost. But, the low sensitivity of them is one of the challenges in these methods ${ }^{5,6}$. In general, RT-PCR, LAMP and RPA methods are the routine methods used to identify COVID-19 which they can use as reliable methods in laboratories ${ }^{7,8}$. Although, the time-consuming and requires extensive laboratory equipment are the problems of this $\operatorname{method}^{9}$. Biosensor can be useful as the tools with high power and sensitivity and a reasonable cost, with usability in a point-of-care test ${ }^{10}$. Because the spikes of the SARS-CoV-2 have a glycan structure ${ }^{11}$, the basics of our screening are about the identification of glycan. So far, many nanomaterials are used as platforms to detect viral particles ${ }^{12,13}$. On the other hand, many artificial receptors have been used to identify the glycan ligands ${ }^{14-16}$. Galectins are the lectin receptors which can act as a receptor/ligand on the surface of exosomes or microparticle vesicles $(\mathrm{MV})^{17}$. Most studies about SARS-CoV-2 have shown that the spike is connected via the CTD-S1 domain with ACE-2. But, a recent study showed the effect of the NTD domain on the binding with GM1 ganglioside to maintain stability ${ }^{18,19}$. Our results were demonstrated the probable effect of NTD-S1 domain binding with glycan by electrochemical behaviors via introducing the MV-gall as a natural receptor-bed with the electrochemical properties, for the first time. Ghazizadeh et al. showed the electrochemical properties of exosomes as a natural bed. They used of the synthetic receptor (p19 protein) to sense of RNA ${ }^{20}$. Here, we use as natural bed-receptor without any synthetic processes. Gal-1 is a natural receptor on the natural bed (MV) which is extracted of marrow-derived mesenchymal stem cells to general screening of every spiked virus. To specific detection of SARS-CoV-2 Antigen, we used as Au@Antibody-SARS-CoV-2 spike to bind the SARS-CoV-2 virus. So, with the addition of MV-gall on the SCPE/GNP, the impedance increased (sensor = ON) due to exchange of charge of gal-1 with $\left[\mathrm{Fe}(\mathrm{CN})_{6}\right]^{-3 /-4}$. Then, with the addition of the inactive SARS-CoV-2 on MV-gal1/SCPE-GNP,

\footnotetext{
${ }^{1}$ Department of Medical Biotechnology, School of Medicine, Mashhad University of Medical Sciences, Mashhad, Iran. ${ }^{2}$ Radiation Biology Research Center, Iran University of Medical Sciences (IUMS), Tehran, Iran. ${ }^{3}$ Yazd Cardiovascular Research Center, Shahid Sadoughi University of Medical Sciences, Yazd, Iran. ${ }^{4}$ Department of Pediatric Hematologist and Oncologist, Bahrami Children Hospital, Tehran University of Medical Sciences, 25529 Tehran, Iran. ${ }^{5}$ Department of Physics, Faculty of Science, University of Tarbiat Modarres, Tehran, Iran. ${ }^{\square}$ email: elhamgenetic@yahoo.com
} 
the impedance decreased by covering of the glycosylation bond. Dropping the Au@Anti-SARS-CoV-2 spike caused to turn on the sensor by electrochemical amplifier of AuNP, again. As a result, we reported a natural bed/receptor (MV-gal1) with Au@Anti-SARS-CoV-2 spike to double sensing of SARS-CoV-2 Antigen with high sensitivity in $\sim 5 \mathrm{~min}$.

\section{Materials and methods}

Materials. All of the materials as analytical grade potassium ferrocyanide, potassium ferricyanide, sulfuric acid, hydrogen peroxide, sodium chloride, and potassium chloride were prepared from Novin Tech Company, IRAN. We used as Virus Transport Medium (VTM) from Nedashimi Co, IRAN. This is a liquid media for the transport of specimens to the laboratory for transport of viruses (including COVID19). We also used as SCPE/ GNP which is functionalized with gold nanoparticles on the ceramic substrate were purchased from DropSens Inc. Gold Nano Particle-Carbon (GNP-carbon) working electrode; a carbon counter electrode and a silver reference electrode are components of the electrode. Electrochemical impedance spectroscopy (EIS) and Differential pulse voltammetry (DPV), were evaluated by SP-300 Instruments (SP-300) Texas, USA. DPV was done in the presence of $1 \mathrm{mM}\left[\mathrm{Fe}(\mathrm{CN})_{6}\right]^{-3 /-4}$ in phosphate buffer saline in the potential window $-0.4 \mathrm{~V}$ to $+0.4 \mathrm{~V}$ at a scan rate $50 \mathrm{mV} \mathrm{s}^{-1}$, and impedance measurement was done between $100 \mathrm{kHz}$ to $1 \mathrm{~Hz}$ of $\left[\mathrm{Fe}(\mathrm{CN})_{6}\right]^{-3 /-4}$ in phosphate buffer saline $\mathrm{pH}=7.4$. ZSimpWin 3.22 Software (Princeton Applied Research) was used for measuring the EIS spectra with the help of equivalent circuit using, and the data were presented in Nyquist plots. AFM was done for the analysis of the surface roughness on a Dimension 3000 instrument (Digital Instruments/Aveco Science). TEM images were done by TecnaiG220 instruments from FEI Company, Hillsboro, USA. We determinate the particle sizes and zeta potentials by Horiba nanoparticle size analyzer, Malvern Nano SZ-100 at wavelength $532 \mathrm{~nm}$.

Experimental autoimmune encephalomyelitis (EAE) induction. We purchased the female C57BL/6 mice at 6-8 weeks old from Pasteur Institute, Iran. Animals were kept under pathogen-free conditions at the animal house of IPIU (Institute Physiology of IRAN University). They were treated according to the National Institute of Health Guide for Care and Use of Laboratory Animals. We have done the EAE induction based on the previous protocol ${ }^{21}$.

Isolation and characterization of microparticle vesicles (MSC). Marrow-derived mesenchymal stem cells (MSC) were harvested from the Tibia and Femurs of healthy C57BL/6 mice by flushing method. Cells were taken to plate in T75 flasks using low-glucose Dulbecco's Modified Eagle's Medium (LG-DMEM; Invitrogen, Carlsbad, CA), after centrifugation at $1500 \mathrm{rpm}$ for $5 \mathrm{~min}$ in Hank's Balanced Salt Solution buffer (HBSS; Invitrogen, Carlsbad, CA). Then we plated the cells containing 15\% fetal bovine serum (FBS; Invitrogen, Carlsbad, CA) and antibiotics. Non-adherent cells were removed after $6 \mathrm{~h}$ incubation at $37^{\circ} \mathrm{C}$ and humidified $5 \% \mathrm{CO}_{2}$. When cultured showed $>70 \%$ confluence, adherent cells were gathered using 10 min with incubation at $37^{\circ} \mathrm{C}$ with $0.05 \%$ trypsin (Invitrogen, Carlsbad, CA) solution containing $0.02 \%$ ethylene diamine tetraacetic acid (EDTA; Sigma-Aldrich, St. Louis, MO) and washed twice with phosphate buffer saline. Harvested cells were transferred into the T25 flasks for sub-culturing ${ }^{21}$. We used the 3rd passage of MSCs (adherent cells) for flow cytometry analysis. Surface expression of stem cell markers characterized using anti-mouse monoclonal antibodies against CD90-PE, and CD73-FITC (all purchased from eBioscience, San Diego, CA). Flow cytometric analyses were performed using a PAS flow cytometer (Partec GmbH, Germany). Cell Quest software was used for data analysis.

Isolation and characterization MV. Isolation of MVs were done as previously published protocol ${ }^{22}$. After collecting the supernatant of MSC culture, they were centrifuged at $300 \times g$ for $10 \mathrm{~min}, 1000 \times g$ for $20 \mathrm{~min}$, and $10,000 \times g$ for $30 \mathrm{~min}$. Then, the final centrifuged supernatant was ultra-centrifuged at $100,000 \mathrm{~g}$ for $2 \mathrm{~h}$ in the ultracentrifuge (Beckman coulter optima TMXL-100K ultracentrifuge. The pelleted MV was washed in saline and again centrifuged at $100,000 \mathrm{~g}$ for $2 \mathrm{~h}$. The suspension pellet was quantified by Bradford assay (SigmaAldrich, St. Louis, MO).

Flow cytometry analysis for MV/gal-1. The MVs $(40 \mu \mathrm{g})$ were incubated with $4 \mu \mathrm{m}$ diameter aldehyde/ sulfate latex beads (Invitrogen, Carlsbad, CA), for $4 \mathrm{~h}$ at $37^{\circ} \mathrm{C}$ with gentle mixing. We use as $100 \mathrm{mM}$ glycine to fill reactive sites on the beads' surface to prevent the coupling reaction was stopped. To form pellet MV-coated beads, the mixture was centrifuged at $3000 \times g$ for $20 \mathrm{~min}^{23}$. Then, the suspension of the pellet in phosphate buffer saline was occurred and then washed three times. MV-coated beads were stained using specific antibodies to CD9 FITC, CD63 Biotin followed by streptavidin PE and Anti-GAL1 FITC (MyBiotech Co).

Virus culture. The infection of corona virus was done in a biosafety level 3 laboratory at Pasteur institute. We use as an African green monkey kidney Vero E6 cells with a clinical isolate of SARS-CoV-2 (https://wwwnc.cdc. gov/travel/notices/covid-4/coronavirus-iran). We collected the culture medium containing mature infectious virus (virus medium), and titration were done by plaque assay. Live virus was inactivated by heating at $100{ }^{\circ} \mathrm{C}$ for $15 \mathrm{~min}$ and was stored at $-80^{\circ} \mathrm{C}$ for further use.

Clinical sample preparation. The clinical samples used in this were collected who Suspicious patients referred to Emad laboratory were used. They provided written informed consent as registration number: EHW 2020-04-07-507). In addition to this laboratory, ethical committed of Iran medical university confirmed 
A
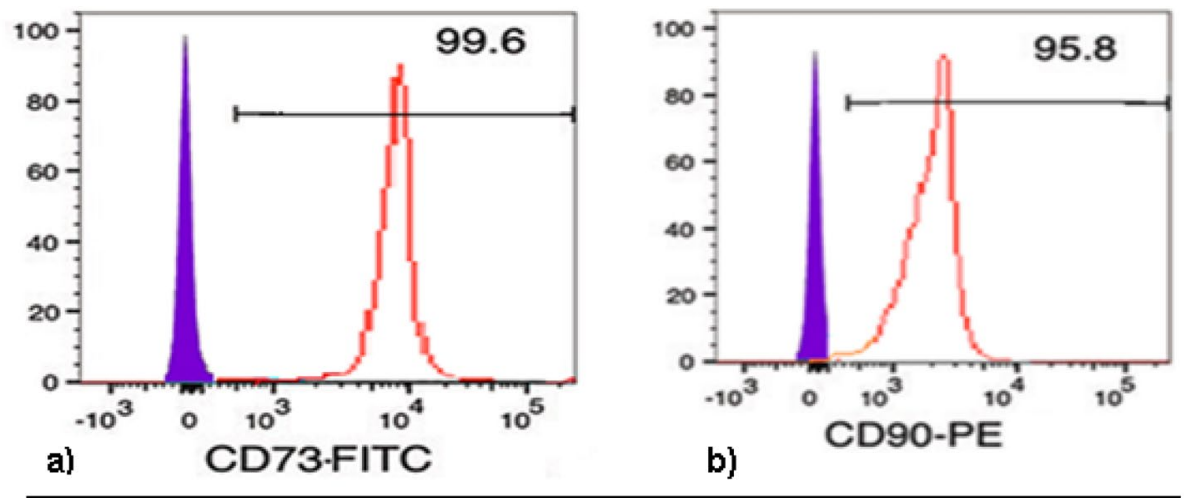

a) CD73.FITC

b)

CD9

B

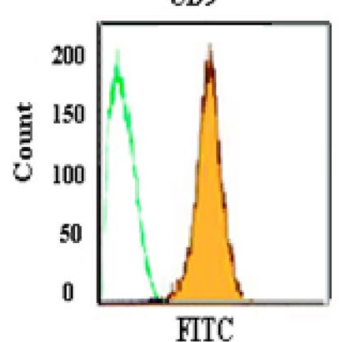

a)

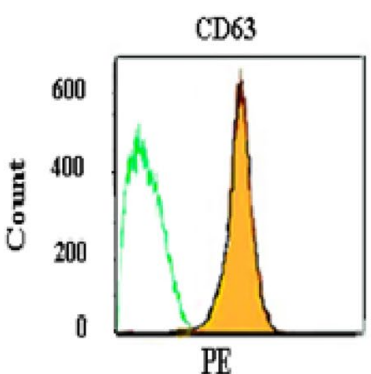

b)

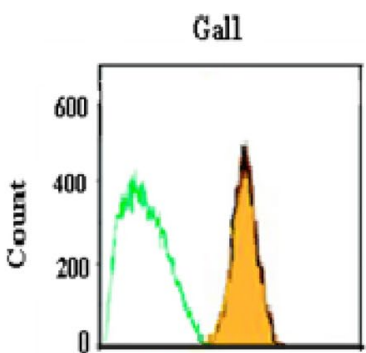

c)

Figure 1. (A) Characterization of mouse bone marrow-derived mesenchymal stem cells. Flow cytometry analyses of cell surface markers showed that cultured cells were positive for mesenchymal stem cell markers of CD90 (99.6\%) (a), CD73 (95.8\%) (b). (B) Flow cytometry analyses of MVs surface markers. MVs coated on sulfate/aldehyde latex beads were positive for the surface expression of CD9 (95.6\%) (a), CD81 (94.8\%) (b), Gal-1 (84.8\%) (c).

that all experiments were performed in accordance with relevant guidelines and regulations with registration code as: 99-1-6-8-17943) Detailed and clinical information of the participants is given in Table S2, as follows human guidelines. Nasopharyngeal swabs from COVID-19 patients and healthy subjects were stored in VTM (NedaShimi, IRAN). Viral copy number was determined by real-time RT-PCR. Clinical samples were inactivated by heating at $100{ }^{\circ} \mathrm{C}$ for $10 \mathrm{~min}$ and were stored at $-80^{\circ} \mathrm{C}$ for further use.

Preparation of MV-gal1/SARS-CoV-2 antigen on the SCPE-GNP. Immobilization of MV-gal1 was done by dropping $5.2 \mu \mathrm{L}$ of MV-gall solution in $50 \mathrm{mM}$ phosphate buffered saline (phosphate buffer saline, $\mathrm{pH}$ 7.4) onto the SCPE/GNP and incubated overnight at $4{ }^{\circ} \mathrm{C}$. After incubation, excess MV-gall was removed by the phosphate buffer saline. Following rinsing, $50 \mu \mathrm{L}$ of blocking solution (1\% BSA in phosphate buffer saline for $1 \mathrm{~h}$ ) was added onto the electrode surface to prevent the nonspecific binding and incubated at $4{ }^{\circ} \mathrm{C}$. Then we use as SARS-CoV-2 Antigen as SARS-CoV-2 Antigen Protein stock (ProSci Incorporated, Co) which was diluted to 100 fold a $5 \mu \mathrm{L}$ of this diluted solution was dropped on the MV-gall/SCPE and incubated overnight at $4{ }^{\circ} \mathrm{C} .3 \%$ BSA was added to the antibody solutions for blocking and minimize the non-specific absorption (NSA). Then, electrochemical tests were done at every stage.

Bioconjugation of gold nanoparticle to Anti-SARS-CoV-2 spike. A mixture of $100 \mu \mathrm{L}$ of AntiSARS-CoV-2 spike $\left(50 \mu \mathrm{g} / \mathrm{mL}\right.$ in $\left.5 \mathrm{mM} \mathrm{KH}_{2} \mathrm{PO}_{4}, \mathrm{pH} 7.5\right)$ (MyBiotech Co) and $700 \mu \mathrm{L}$ of $0.1 \%$ Au nanoparticle solution was prepared a kept for $50 \mathrm{~min}$ at room temperature. We add $50 \mu \mathrm{L}$ of $1 \% \mathrm{PEG}$ in $5 \mathrm{mM} \mathrm{KH}_{2} \mathrm{PO}_{4}$ solution $(\mathrm{pH}=7.5)$ and $100 \mu \mathrm{L}$ of $10 \% \mathrm{BSA}$ in $50 \mathrm{mM} \mathrm{KH}_{2} \mathrm{PO}_{4}$ solution ( $\mathrm{pH}$ 9.0) to block any uncovered surface on the AuNPs. The AuNP conjugated Anti-Cov-2 (Au/Anti-SARS-CoV-2 spike) was then collected via centrifugation $\left(8000 \mathrm{~g}\right.$ for $15 \mathrm{~min}$ at $\left.4{ }^{\circ} \mathrm{C}\right)$. Au/Anti-SARS-CoV-2 spike were suspended in $1 \mathrm{~mL}$ of preservation solution (1\% BSA, $0.05 \%$ PEG 20000, $0.1 \% \mathrm{NaN}_{3}$ and $150 \mathrm{mM} \mathrm{NaCl}$ in $20 \mathrm{mM}$ Tris $\mathrm{HCl}$ buffer, $(\mathrm{pH}=8.2)$, and centrifuged again to collect the Au/Anti-SARS-CoV-2 spike. and stored as stock solution.

Sandwiched Au/Anti-SARS-CoV-2 spike on the MV-gal1/SARS-CoV-2 antigen protein SCPE-GNP. The Au/Anti-SARS-CoV-2 spike stock solution was diluted to tenfold and $6 \mu \mathrm{L}$ of this diluted solution was dropped onto the MV-gal1/SARS-CoV-2 Antigen Protein. After incubation for 30 min at room temperature, the surface was left for $1 \mathrm{~h}$ and washed with blank phosphate buffer saline. So, the electrochemical tests were done, again. 

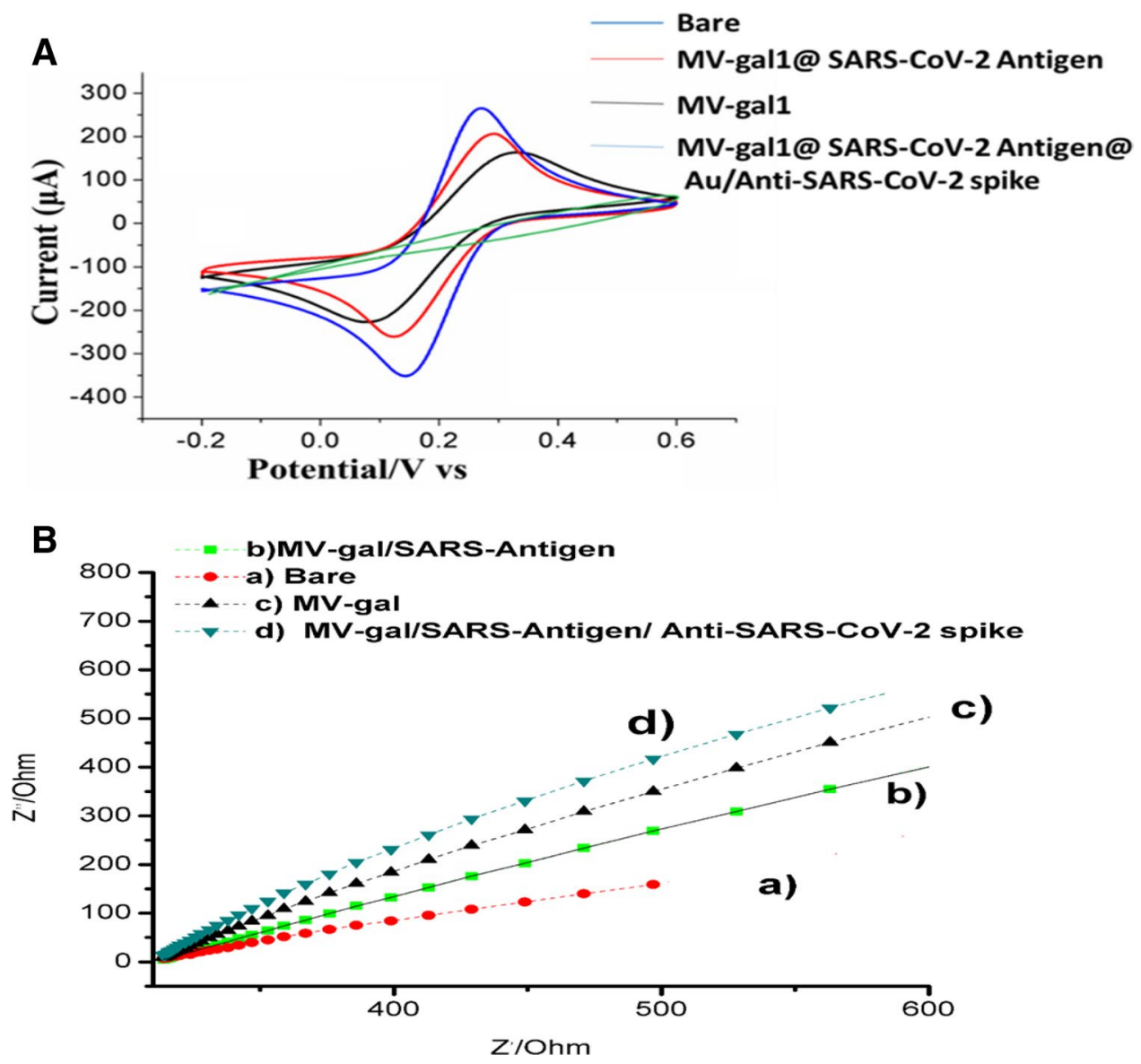

Figure 2. (A,B) DPV and EIS behaviors about and EIS images about fabrication of MV-gal1@SARS-CoV-2 Antigen@Au/Anti-SARS-CoV-2 spike on the SCPE-GNP. Data recorded at the scan rate $50 \mathrm{mV} \mathrm{s}^{-1}$ in phosphate buffer $(\mathrm{pH} 7.4)$ containing $1 \mathrm{mM}\left[\mathrm{Fe}(\mathrm{CN})_{6}\right]^{-3 /-4}$.

\section{Results}

MSC and MVs characterization. There was a homogenous population of MSCs which obtained from C57BL/6 mice after 3 passages in vitro. Flow cytometry analyses show the expression of CD90 and CD73 (Fig. 1A). Analyses of MVs by electron microscope showed the presence of nano-sized vesicles which size of them at the range of 50 and $200 \mathrm{~nm}$ (Fig. S1). In MVs, flow cytometry analyses were positive for the expression of surface markers of CD9, C63, and Gal-1 (Fig. 1B).

Fabrication and characterization of bio sensing MV-gal1@SARS-CoV-2 Antigen@Au/ Anti-SARS-CoV-2 spike on the SCPE-GNP. Immobilization of every material on the GNP-SCPE showed the different differential pulse voltammetry in the presence of $1 \mathrm{mM}$ in phosphate buffer saline (Fig. 2A,B). At first, the Bare gold electrode showed the $\Delta \mathrm{E}(\mathrm{Epa}-\mathrm{Epc}) 75 \mathrm{mV}$ in the $\left[\mathrm{Fe}(\mathrm{CN})_{6}\right]^{-3 /-4}$ redox probe. Attachment of the MV-gall on the GNP-SCPE was done by direct drop casting ${ }^{24}$ and showed the peak currents decreased from 14.3 to $13.9 \mu \mathrm{A}$ and the $\Delta \mathrm{Ep}$ increased from 75 to $83 \mathrm{mV}$, due to the increasing the electrochemical reaction with the receptors on the MV with the $\left[\mathrm{Fe}(\mathrm{CN})_{6}\right]^{-3 /-4}$ redox probe. A recent study of Ghazizadeh, showed that exosomes have the electrochemical properties on the SCPE-GNP20,25]. Our results about MV are overlap with considering they are larger microparticles with the similar exosomal properties. Adding the SARS-CoV-2 Antigen on the MV-gal1/SCPE-GNP shows that the peak currents increased from 13.9 to $15.4 \mu \mathrm{A}$ and the $\triangle \mathrm{Ep}$ decreased from 83 to $73 \mathrm{mV}$, due to covering the glycosylation bond by gall and glycan of spike of SARS-CoV-2. A recent study of Kajiyazdi was showed that covering the glycosylation bonds when lectin used as a synthetic receptor to identify the glycan on the tumor cells of AML disease 26,27 . Our results indicate the possible connection of the gall with NTD-domain (Glycan domain) of the SARS-CoV-2 Antigen by increasing the current peak, which it causes to the reduction of electrochemical exchanges with the $\left[\mathrm{Fe}(\mathrm{CN})_{6}\right]^{-3 /-4}$ redox probe, too. At the end, adding the Au@Anti-SARS-CoV-2 spike on the MV-gal1/SARS-CoV-2 Antigen/SCPE-GNP shows the decreasing in peck current, again $(15.4-14.2 \mu \mathrm{A})$ and $\Delta \mathrm{Ep}$ increased from 73 to 89 due to amplify reactions of AuNP with $\left[\mathrm{Fe}(\mathrm{CN})_{6}\right]^{-3 /-4}$ redox pro.

In fact, we used in the study of direct adsorption of AuNP with Anti-SARS-CoV-2 spike to form the Au@ Anti-SARS-CoV- ${ }^{28}$. In order to ensure the binding of AuNP to the Anti-SARS-CoV-2 spike, we used MV-gal1@ SARS-CoV-2 Antigen@Anti-SARS-CoV-2 (Without AuNP as control) in the electrochemical reaction of DPV, 

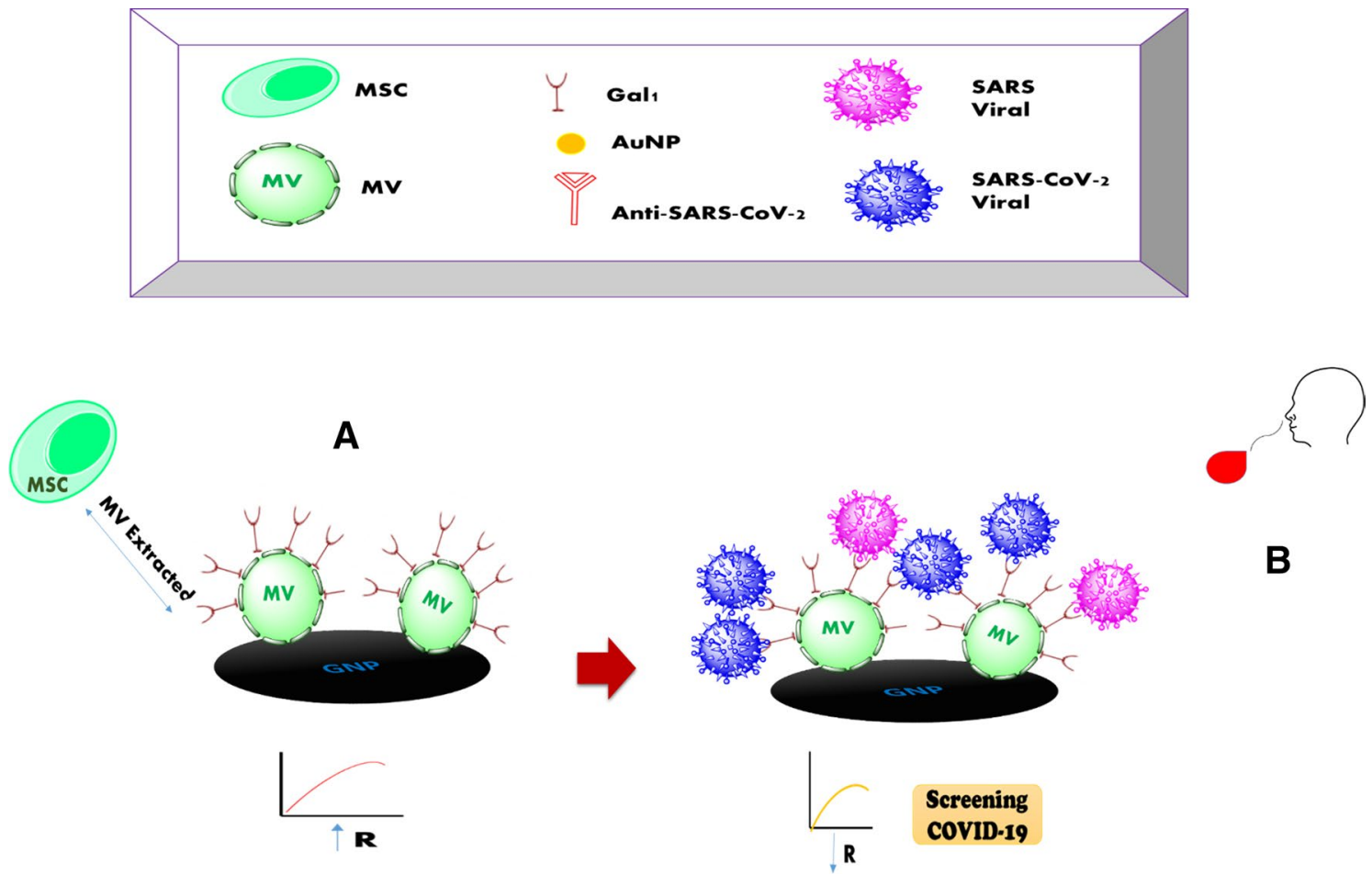

B
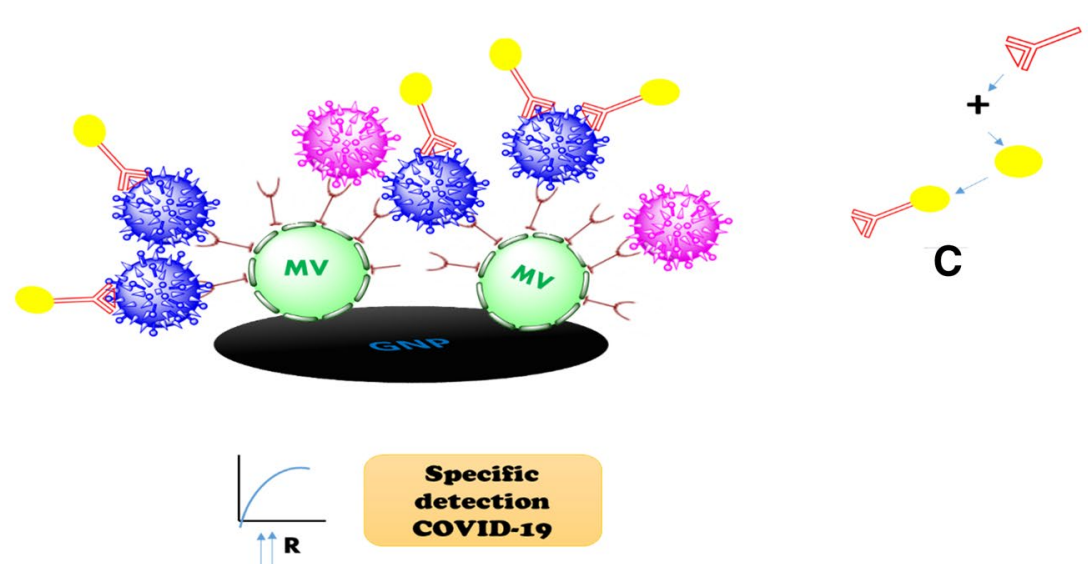

Figure 3. Schematic schema for the stages of screening and specific detection of COVID-19 based on electrochemical biosensor. (A) Immobilization of MV-gall on the SCPE-GNP. (B) Dropping the SARS-CoV-2 on the MV-gal1-SCPE-GNP to screening the spiked COVID-19. (C) Dropping the Au/Anti-SARS-CoV-2 spike On the MV-gal1@SARS-CoV-2 Antigen to specific detection of COVID-19.

which showed a noticeable decrease in MV-gal1@SARS-CoV-2 Antigen@Au/Anti-SARS-CoV-2 relative to MVgal1@SARS-CoV-2 Antigen@Anti-SARS-CoV-2 (73-65 $\Delta \mathrm{Ep})$. These results indicate the binding and effect of gold nanoparticles on antibodies and increase in electrochemical exchanges (Fig. S5).

In research of Dianyun showed that gold nanoparticle (AuNP) can act as an electrochemical amplifier to detection human chorionic gonadotropin (hCG) which it is used as a label with the second $\mathrm{AB}^{29}$. Not only, adding the Au@Anti-SARS-CoV-2 spike on the MV-gal1@SARS-CoV-2 Antigen show the specific SARS-CoV-2 Antigen (specific detection) with the increase in the electrochemical reaction of AuNP with $\left.\mathrm{Fe}(\mathrm{CN})_{6}\right]^{-3 /-4}$ probe, but only it can prove the connection of MV-gall with glycans of SARS-CoV-2 which happened in first step, too. So at this point, it may confirm the connection of gal-1 on the MV with the spike of SARS-CoV-2 based on the NTD-domains. We also verified the effect of bonding of glycans in attachment with receptors based on the electrochemical reactions. We use as the EIS to identify the modified electrode with surface properties. The impedance behaviors of the respective layers are reported in Fig. 2B. Two equivalent circuits viz., Rs(Qdl(RCTW)) and $\operatorname{Rs}(\mathrm{Qdl}(\mathrm{RCTW})(\mathrm{CRL}))$ were used as model to show the impedance data. Rs(Qdl(RCTW)) will use for further analysis if the $\operatorname{Rs}(\mathrm{Qdl}(\mathrm{RCTW})(\mathrm{CRL}))$ circuit does not fit well with all surfaces studied. So, Rs shows the solution resistance; $\mathrm{Qdl}$ and $\mathrm{R}_{C T}$ are capacitance (constant phase element) and charge transfer resistance of the gold electrode respectively; RL is the layer resistance and W is Warburg element. In corroboration with the DPV results, 
A

a)

b)

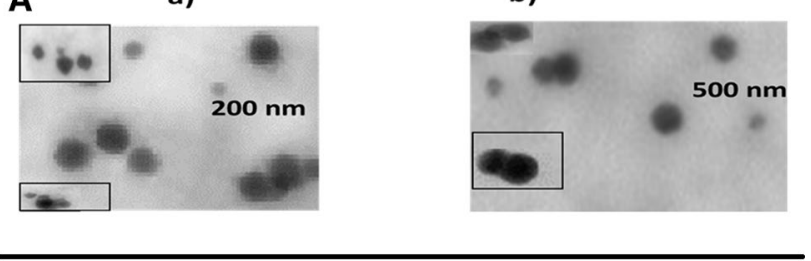

MV-GAL1/ SARS-CoV-2

B
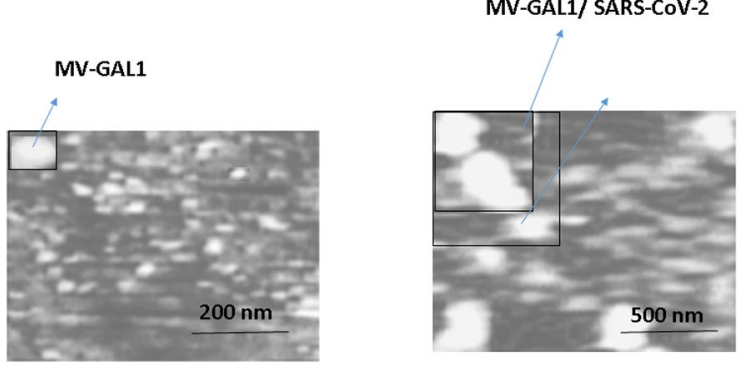

Figure 4. (A) TEM images of MV-gall (a) and MV-gal1@SARS-CoV-2 virus (b) to show the modified SCPE/ GNP. (B) AFM images when adding of MV-gall (a) and MV-gal1@SARS-CoV-2 virus (b) were occurred on the SCPE/GNP.

the $\mathrm{R}_{C T}$ value is $5.32 \times 10^{4} \Omega \mathrm{cm}^{-2}$ for the bare gold electrode. $\mathrm{R}_{C T}$ value increased to $6.58 \times 10^{4} \Omega \mathrm{cm}^{-2}$ when adding the MV-gall and decreased to $5.83 \times 10^{4} \Omega \mathrm{cm}^{-2}$ with added SARS-CoV-2 Antigen on the MV-gall. At the end, $\mathrm{R}_{C T}$ value increased again to $7.32 \times 10^{4} \Omega \mathrm{cm}^{-2}$ when the Au@Anti-SARS-CoV-2 spike was dropped on the modified surface. The schematic figure of every steps of modified sensor were described in Fig. 3. The AFM image of the MV-gal1/SCPE-GNP surface becomes smoother following the hybridization by adding SARS-CoV-2 virus compare to rough surface of the MV-gall because of higher sizer materials (adding SARS-CoV-2 viral) than MV-gall with providing the electrostatic blockade for the linear diffusion of the $\left[\mathrm{Fe}(\mathrm{CN})_{6}\right]^{-3 /-4}$ directly to the electrode surface (Fig. $4 \mathrm{~B}(\mathrm{~b})$ ). To identify the interaction of each component on the modified SCPE/GNP sensor, TEM images have been used. Figure 4A panel (a) shows the TEM images of the modified MV-gall at higher magnification, $\sim 300 \mathrm{~nm}$. The interaction of SARS-CoV-2 virus on MV-gall has shown with the increased size of the $\sim 650 \mathrm{~nm}$. (Fig. $4 \mathrm{~A}(\mathrm{~b})$.

Dual sensing of SARS-CoV-2 antigen protein. To investigate the performance of the MV-gal1/SCPEGNP sensor, we evaluated the response of the sensor to SARS-CoV-2 Antigen Protein. First, we showed the LOD of sensor for spike protein when it connected to MV-gall. Our devise sensed to $500 \mathrm{fg} / \mathrm{mL}$ of SARS-CoV-2 spike protein in phosphate buffer saline (Fig. 5A). The $j$ value increases linearly with increasing the concentration of SARS-CoV-2 spike protein ranged from $1 \mu \mathrm{g} / \mathrm{mL}$ to $500 \mathrm{fg} / \mathrm{mL}$. A regression equation of $\mathrm{y}=10.973 \mathrm{x}+30.456$ $\left(\mathrm{R}^{2}=0.976\right)$ was obtained, where $\mathrm{y}$ is the $\mathrm{j}$ value in $\mu \mathrm{A} \mathrm{cm}{ }^{-2}$ and $\mathrm{x}$ is the logarithmic concentration of SARSCoV-2 spike protein in $\mu \mathrm{g} / \mathrm{mL}$. The sensor responded the LOD $(1 \mathrm{fg} / \mathrm{mL})$ with lower sensing of SARS-CoV-2 spike protein in phosphate buffer saline when the Au@Anti-SARS-CoV-2 spike was added on the SCPE-GNP electrode. A regression equation of $y=12.763 x+30.456\left(R^{2}=0.976\right)$ was obtained, where $y$ is the $j$ value in $\mu \mathrm{A} \mathrm{cm}^{-2}$ and $\mathrm{x}$ is the logarithmic concentration of SARS-CoV-2 spike protein in fg/Ml (Fig. 5C,D). So, it can indicate high sensitivity and specificity for detection of the SARS-CoV-2 spike antigen. Also, it can be proved that the connection of MV-gall with glycan of SARS-CoV-2 spike protein which it can cause the connection of Au@Anti-SARS-CoV-2 spike via another specific part of SARS-CoV-2 spike protein. To diagnosis of COVID-19 is performed using nasopharyngeal swabs suspended in transport medium (VTM). So, we used as our sensor to detection of SARS-CoV-2 Antigen protein in Universal Transport Medium (UTM). However, the presence of various reagents such as salts and non-specific factors can affect the performances of the sensor, but our sensor can sense SRS-CoV-2 spike proteins in $0.01 \times$ VTM with starting from a concentration of $1 \mu \mathrm{g} / \mathrm{mL}$ when it attached to the MV-gal1/SCPE-GNP sensor and $500 \mathrm{fg} / \mathrm{mL}$ when adding of the Au@Anti-SARS-CoV-2 spike was occurred (Fig. S2A,B). So, our device can screen and specific detection of the COVID-19 samples in two steps without any preparation or preprocessing.

Sensing of SARS-CoV-2 virus from clinical samples. Our sensor was used to show the functionality of COVID-19 in clinical samples (Fig. 5). So, we collected the nasopharyngeal swab specimens from COVID-19 patients (Emad laboratory) and normal subjects and stored them in VTM (Table S1). We optimize the nasopharyngeal swab samples relate to normal subjects with DPV analysis to determine the basal signal (Fig. S3). Then, our sensor responded to patient samples diluted as much as $2: 1 \times 10^{5}(610$ copies $/ \mathrm{mL})$ with the overall regression equation of $y=11.321 x+29.512\left(R^{2}=0.973\right)($ Fig. $5 E, F)$. At end, sensor diluted as much as $1: 4 \times 10^{5}$ and sensed (457 copies/mL) when faced with specific antibody (Au@Anti-SARS-CoV-2 spike) in following the regression equation of $y=12.124 x+20.512\left(R^{2}=0.989\right)$ (Fig. $\left.5 \mathrm{G}, \mathrm{H}\right)$. Because of the various reagents and generates noise signals of VTM includes, we consider the LOD of the COVID-19 sensor to be low enough for practical 
A

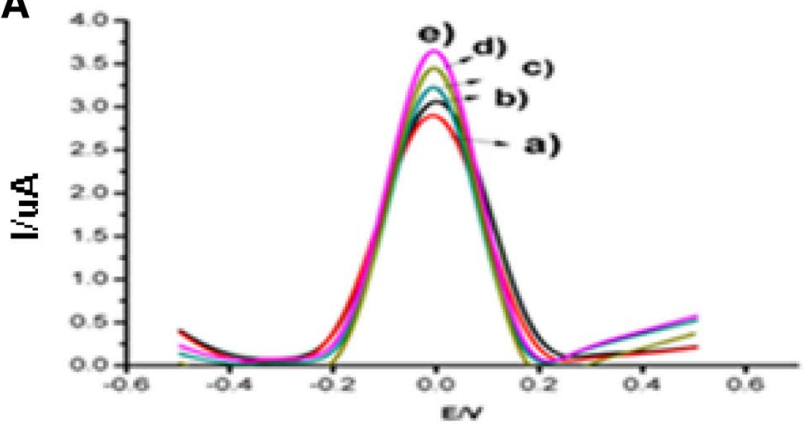

C

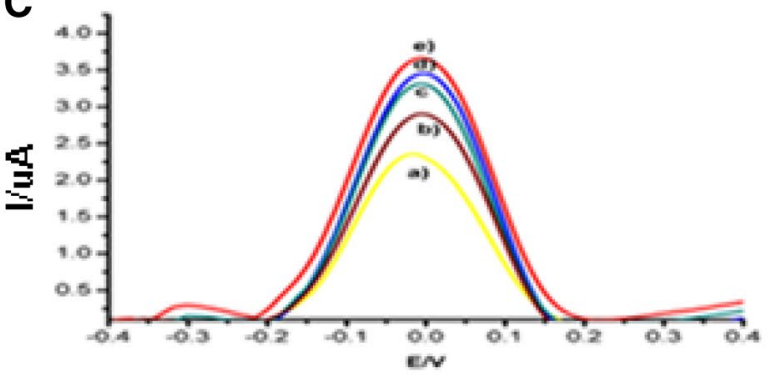

E

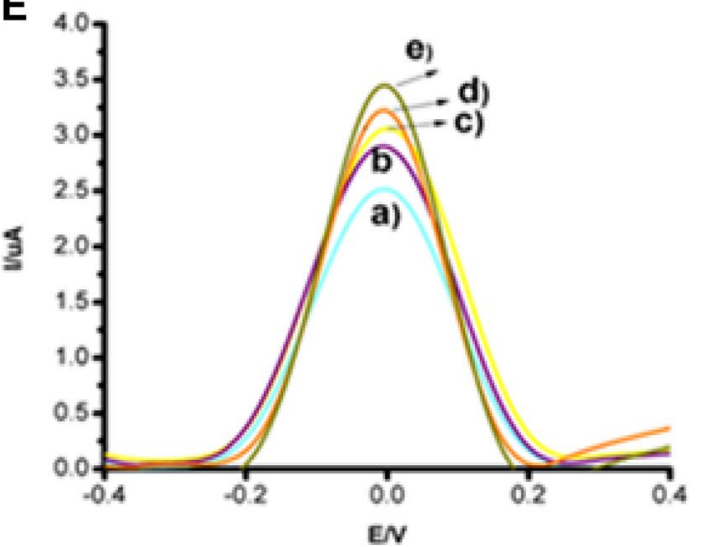

G

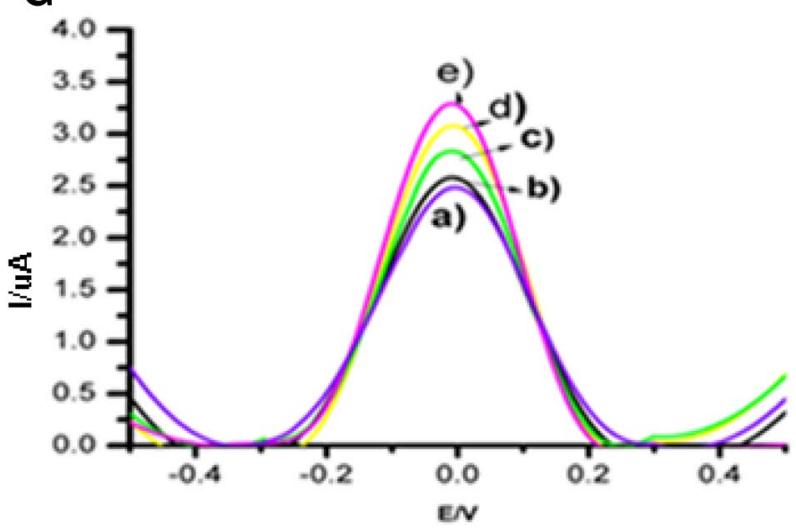

B

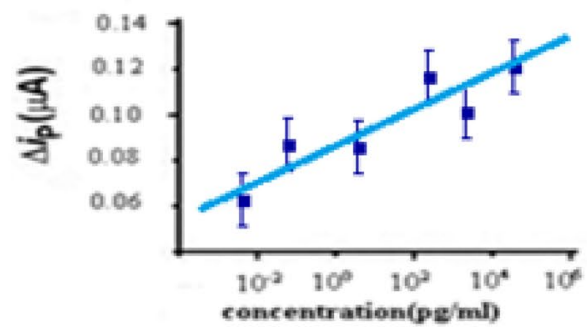

D

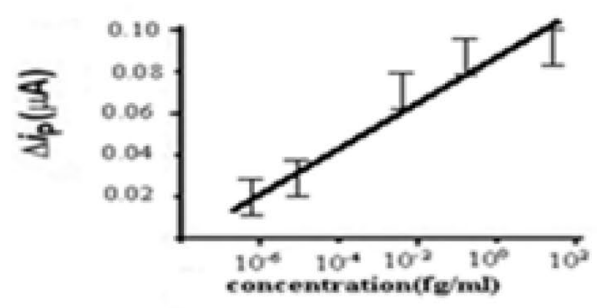

F

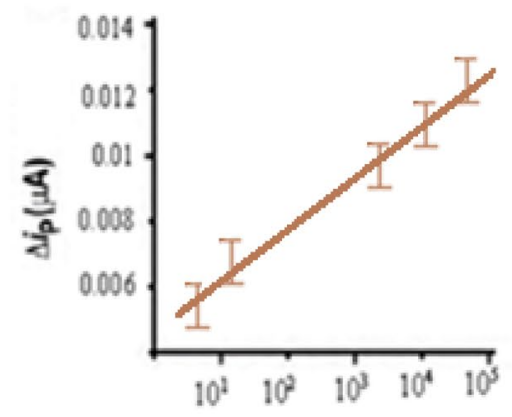

Concemtration(coples/m)

H

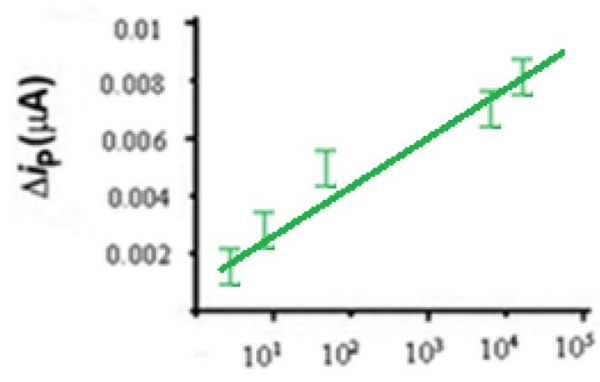

Concemtration(copies/ml)

Figure 5. The performance of the sensor for screening and specific detection of SARS-CoV-2 in vitro and clinical samples using DPV measured at a scan rate $50 \mathrm{mV} \mathrm{s}^{-1}$ in phosphate buffer ( $\mathrm{pH}$ 7.4). (A) Screening of SARS-CoV-2 Antigen based on DPV images using the $1 \mu \mathrm{g} / \mathrm{mL}$ (e) to $500 \mathrm{fg} / \mathrm{mL}$ (a) on the MV-gall/SCPE-GNP in vitro. (B) A calibration plot of the current density vs log concentration of SARS-CoV-2 Antigen. (C) Specific detection of SARS-CoV-2 Antigen based on DPV images using the $11 \mathrm{fg} / \mathrm{mL}$ (e) to $250 \mathrm{pg} / \mathrm{mL}$. (D) A calibration plot of the current density vs log concentration of SARS-CoV-2 Antigen, in vitro. (E) SARS-CoV-2 Virus screening from clinical samples based on DPV. (F) A calibration plot of the current density vs log concentration of SARS-CoV-2 virus (copies/mL). (G) Detection of specific SARS-CoV-2 Virus from clinical samples based on DPV. (H) A calibration plot of the current density vs log concentration of SARS-CoV-2 virus (copies $/ \mathrm{mL}$ ). 


\begin{tabular}{|l|l|l|l|l|l|l|l|}
\hline \multirow{2}{*}{ Sample volume $^{1}$} & Detection target & Detection method & $\begin{array}{l}\text { Sensitivity (true } \\
\text { positive rate }{ }^{2}\end{array}$ & $\begin{array}{l}\text { Specificity (true } \\
\text { negative rate }{ }^{3}\end{array}$ & $\begin{array}{l}\text { Assay detection } \\
\text { time }\end{array}$ & Real samples & References \\
\hline & $\begin{array}{l}\text { SARS-COV-2 spike } \\
\text { S1 }\end{array}$ & Gr-FET & $0.2 \mathrm{pM}$ & - & About 2 min & - & Tan et al. ${ }^{28}$ \\
\cline { 2 - 7 } & $\begin{array}{l}\text { SARS-COV-2 spike } \\
\text { S1 }\end{array}$ & Gr-FET & $2.4 \times 10^{2}$ copies $/ \mathrm{mL}$ & - & $>1$ min & $\begin{array}{l}\text { Swab samples/cul- } \\
\text { tured viruses }\end{array}$ & Mahari et al..$^{13}$ \\
\cline { 2 - 7 } & $\begin{array}{l}\text { SARS-COV-2 spike } \\
\text { S1 }\end{array}$ & $\begin{array}{l}\text { MV-gal1@Au/Anti- } \\
\text { SARS-CoV-2 }\end{array}$ & $4.57 \times 10^{2}$ copies $/ \mathrm{mL}$ & & $>5$ min & Swab samples & This study \\
\hline
\end{tabular}

Table 1. Comparison the biosensor methods to detection of surface antigen of SARS-COV2. ${ }^{1}$ The sensitivity of a clinical test refers to the ability to correctly identify those patient samples (also called the true positive rate) (Lalkhen and McCluskey ${ }^{30}$ ). ${ }^{2}$ The specificity of a clinical test refers to the ability to correctly identify those non-patient samples (also called true negative rate) (Lalkhen and $\mathrm{McCluskey}^{30}$ ).

use, for example $<457$. Our sensor can also screen and detect the SARS-CoV-2 virus from clinical samples without any preprocessing as using in point-of-care tests. Our results are summarized with other biosensors which they used for direct detection of surface antigen or whole viruses of SARS-CoV-2 in the Table 1.

Reproducibility and stability of MV-gal1@Au/Anti-SARS-CoV-2 spike to sense the SARS-CoV-2 virus on the SCPE-GNP. The virus concertation of $1 \times 10^{5}$ (virus particle $/ \mathrm{mL}^{-1}$ ) relate to the MV-gall sensing and $1: 4 \times 10^{5}$ (virus particle $/ \mathrm{mL}^{-1}$ ) relate to the Au/Anti-SARS-CoV-2 spike, was showed the standard deviation of $4.9 \%$ and $5.3 \%$ examined for five measurements, respectively with a showing good reproducibility (Fig. S4a). Our results also show the perfect response after 35 successively scanning, suggesting the acceptable durability of this method (Fig. S4b). Calibration results were reported in (Table S1) for MV-gal1@SARS-CoV-2 Antigen@Au/Anti-SARS-CoV-2 spike sensors.

Clinical validation of MV-gal1@Au/Anti-SARS-CoV-2. To improve validation of clinical samples based on our sensor, percent positive agreement (PPA) and negative percent agreement (NPA) were calculated. Real time test included (E gene and N2 gene) was used by Emad laboratory. Our sensed samples by MV-gal1@ Au/Anti-SARS-CoV-2 achieved a PPA of 96.38\% (93\% CI 93.64-95.96\%) and NPA 98.46\% (98\% CI 93.8499.00\%) (Table S3). Two false negative sample by MV-gal1@Au/Anti-SARS-CoV-2 Were positive by Real time PCR. On the hand, one positive sample by MV-gal1@Au/Anti-SARS-CoV-2 was negative by Real time PCR.

Statement on human guidelines. The clinical samples used in this were collected who suspicious patients referred to Emad laboratory were used. Ethical committed of Iran medical university confirmed that all experiments were performed in accordance with relevant guidelines as the declaration of Helsinki and regulations with registration code as: 99-1-6-8-17943. We also confirmed that experimental protocols were approved by Iran University of medical science and with financial committee by including a statement in the methods section to this effect, including any relevant details. We explained about human samples in section "Clinical sample preparation" and Table S2.

Consent for publication. The graphic figure was prepared by Dr. Elham Ghazizadeh.

Statement confirming. All our results have been achieved realistically and with great effort during the Corona pandemic in IRAN and our research were carried out in compliance with the ARRIVE guidelines.

\section{Conclusion}

In the development of the COVID-19 pandemic, it is necessary to design the sensors to enhance screening and specific detection for COVID-19 in a short time ${ }^{31,32}$. For the first time, we designed a dual-sensor based on MV-gal1/Au@Anti-SARS-CoV-2 spike to detection SARS-CoV-2 Antigen. We used of the MV-gall to general screening of any spike virus. We introduce the natural bed-receptor (MV-gal1) with electrochemical reactions in solid sensor with can bind to glycan of any virus. At the end, using the Au@Antibody-SARS-CoV-2 spike cause to specific bind with the SARS-CoV-2 Antigen. So, our dual-platform has the ability of screening for any spike virus (at the first step) and specific detection of SARS-CoV-2 with high sensitivity (second step) in the solid biosensor. However, there are need more in vivo studies with more sample size to validate this sensor for another spike virus and SARS-CoV-2.

Received: 22 July 2021; Accepted: 29 October 2021

Published online: 26 November 2021

\section{References}

1. CDC. Distribution of novel coronavirus pneumonia. http://2019ncov.chinacdc.cn/2019-nCoV/ (2020).

2. Peiris, J. S. et al. Coronavirus as a possible cause of severe acute respiratory syndrome. Lancet 361(9366), 1319-1325. https://doi. org/10.1016/s0140-6736(1303)13077-13072 (2003) 
3. Lu, H., Stratton, C. W. \& Tang, Y. W. Outbreak of pneumonia of unknown etiology in Wuhan China: The mystery and the miracle. J. Med. Virol. 92(4), 401-402 (2020).

4. Centers for Disease Control and Prevention. Information for laboratories 2019-nCoV requests for diagnostic panels and virus. https://www.cdc.gov/coronavirus/2019-ncov/lab/rt-pcr-panelprimer-probes.htm (2019).

5. Lau, S. K. et al. Detection of severe acute respiratory syndrome (SARS) coronavirus nucleocapsid protein in SARS patients by enzyme-linked immunosorbent assay. J. Clin. Microbiol. 42(7), 2884-2889. https://doi.org/10.1128/JCM.2842.2887.2884-2889. 2004 (2004).

6. Sastre, P. et al. Differentiation between human coronaviruses NL63 and 229E using a novel double-antibody sandwich enzymelinked immunosorbent assay based on specific monoclonal antibodies. Clin. Vaccine Immunol. 18(1), 113-118. https://doi.org/ 10.1128/CVI.00355-00310 (2011).

7. Wu, W. \& Tang, Y. W. Emerging molecular assays for detection and characterization of respiratory viruses. Clin. Lab. Med. 29(4), 673-693. https://doi.org/10.1016/j.cll.2009.1007.1005 (2009).

8. Yan, Y., Zhang, S. \& Tang, Y. W. Molecular assays for the detection and characterization of respiratory viruses. Semin. Respir. Crit. Care Med. 32(4), 512-526. https://doi.org/10.1055/s-0031-1283288 (2011).

9. Beal, S. G. et al. Performance and impact of a CLIA-waived, point-of-care respiratory PCR Panel in a pediatric clinic. Pediatr. Infect. Dis. J. 39(3), 188-191. https://doi.org/10.1097/INF.0000000000002544 (2020).

10. Samson, R., Navale, G. R. \& Dharne, M. S. Biosensors: Frontiers in rapid detection of COVID-19. Biotech 10, 385 (2020).

11. Acquah, C. et al. Deploying aptameric sensing technology for rapid pandemic monitoring. Crit. Rev. Biotechnol. 36, 1010-1022. https://doi.org/10.3109/07388551.2015.1083940 (2016).

12. Caygill, R. L., Blair, G. E. \& Millner, P. A. A review on viral biosensors to detect human pathogens. Anal. Chim. Acta 681, 8-15. https://doi.org/10.1016/j.aca.2010.09.038 (2010).

13. Mahari, S., Roberts, A., Shahdeo, D. \& Gandhi, S. eCovSens-ultrasensitive novel in-house built printed circuit board based electro chemical device for rapid detection of nCovid-19. bioRxiv. https://doi.org/10.1101/2020.04.24.059204 (2020).

14. Kveton, F., Blsakova, A., Kasak, P. \& Tkac, J. Glycan nanobiosensors. Nanomaterials 10, 1406 (2020).

15. Hushegyi, A., Klukova, L., Bertok, T. \& Tkac, J. Carbohydrate nanotechnology and its application to biosensor development. In Carbohydrate Nanotechnology 387-421 (Wiley, 2015).

16. Chou, F.-C., Chen, H.-Y., Kuo, C.-C. \& Sytwu, H.-K. Role of galectins in tumors and in clinical immunotherapy. Int. J. Mol. Sci. 19, 430. https://doi.org/10.3390/ijms19020430 (2018).

17. Caniglia, J. L., Guda, M. R., Asuthkar, S., Tsung, A. J. \& Velpula, K. K. A potential role for Galectin-3 inhibitors in the treatment of COVID-19. PeerJ https://doi.org/10.7717/peerj.9392 (2020).

18. Fantini, J., Di Scala, C., Chahinian, H. \& Yahi, N. Structural and molecular modelling studies reveal a new mechanism of action of chloroquine and hydroxychloroquine against SARS-CoV-2, infection. Int. J. Antimicrob. Agents 55(5), 105960. https://doi.org/ 10.1016/j.ijantimicag.2020.105960 (2020).

19. Mokarizadeha, A. et al. Microvesicles derived from mesenchymal stem cells: Potent organelles for induction of tolerogenic signaling. Immunol. Lett. 147, 47-54 (2012).

20. Ghazizadeh, E., Naseri, Z., Jaafari, M. R., Forozandeh-Moghadam, M. \& Hosseinkhani, S. A fires novel report of exosomal electrochemical sensor for sensing micro RNAs by using multi covalent attachment p19 with high sensitivity. Biosens. Bioelectron. 113, 74-81 (2018).

21. Zappia, E. et al. Mesenchymal stem cells ameliorate experimental autoimmune encephalomyelitis inducing T cell anergy. Blood 106(5), 1755-1761 (2005).

22. Théry, C., Amigorena, S., Raposo, G. \& Clayton, A. Isolation and characterization of MVs from cell culture supernatants and biological fluids. In Current Protocols in Cell Biology (eds Bonifacino, J. S. et al.) 1-29, Unit 3.22 (Wiley, 2006).

23. Bhatnagar, S., Shinagawa, K., Castellino, F. J. \& Schorey, J. S. MVs released from macrophages infected with intracellular pathogens stimulate a proinflammatory response in vitro and in vivo. Blood 110(9), 3234-3244 (2007).

24. Yazdi, M. K., Ghazizadeh, E., Noroozi, M. \& Neshastehriz, A. Design of a DOPC-MoS2/AuNP hybrid as an organic bed with higher amplification for miR detection in electrochemical biosensors. Anal. Bioanal. Chem. 412, 3209-3219 (2020).

25. Ghazizadeh, E., Hosseinkhanib, S., Oskueea, R. K., Molaabasic, F. \& Jaafari, M. R. Sequential or multiplex electrochemical detection of miRs based on the p19 function relative to three sandwiches of different structural hybrids on the liposomal sensor. Mater. Sci. Eng. C 4931(17), 33550-33556 (2018).

26. Yazdia, M. K., Ghazizadeh, E. \& Neshastehriz, A. Different liposome patterns to detection of acute leukemia based on electrochemical cell sensor. Anal. Chim. Acta 1109, 122-129 (2020).

27. Ghazizadeh, E., Moosavifard, S. E., Daneshmand, N. \& Kaverlavani, S. K. Impediometric electrochemical sensor based on the inspiration of carnation Italian ringspot virus structure to detect an Attommolar of miR. Sci. Rep. 10, 9645 (2020).

28. Tan, E. et al. Use of the lateral flow immunoassay to characterize SARS-CoV-2 RBD-specific antibodies and their ability to react with the UK, SA and BR P.1 variant RBDs. Diagnostics 11, 1190 (2021).

29. Choi, J. R. Development of point-of-care. Biosensors for COVID-19. Front. Chem. 8, 517 (2020).

30. Lalkhen, A. \& McCluskey, A. Clinical tests: sensitivity and specificity, Medicine 107-101 (2009).

31. He, J.-L. et al. Diagnostic performance between CT and initial real-time RT-PCR for clinically suspected 2019 coronavirus disease (COVID-19) patients outside Wuhan, China. Respir. Med. 168, 105980 (2020).

32. Hu, T. Y., Frieman, M. \& Wolfram, J. Insights from nanomedicine into chloroquine efficacy against COVID-19. Nat. Nanotechnol. 15, 247-249 (2020).

\section{Acknowledgements}

Authors thank Iran University of Medical Sciences for support this project as project (99-1-6-8-17943) and EMAD laboratory and Pasteur Institute to provide samples of inactive Covid-19 patients.

\section{Author contributions}

Everyone contributed equally to this article. A.N.z is corresponding, and E.G. do this research, A.D. helped in analyzing and E.S. prepare lab, S.E. prepared figures and M.K.Y. wrote this research. Figure 3 was created by E.G.

\section{Competing interests}

The authors declare no competing interests.

\section{Additional information}

Supplementary Information The online version contains supplementary material available at https://doi.org/ 10.1038/s41598-021-02029-0.

Correspondence and requests for materials should be addressed to E.G. 
Reprints and permissions information is available at www.nature.com/reprints.

Publisher's note Springer Nature remains neutral with regard to jurisdictional claims in published maps and institutional affiliations.

(c) (i) Open Access This article is licensed under a Creative Commons Attribution 4.0 International License, which permits use, sharing, adaptation, distribution and reproduction in any medium or format, as long as you give appropriate credit to the original author(s) and the source, provide a link to the Creative Commons licence, and indicate if changes were made. The images or other third party material in this article are included in the article's Creative Commons licence, unless indicated otherwise in a credit line to the material. If material is not included in the article's Creative Commons licence and your intended use is not permitted by statutory regulation or exceeds the permitted use, you will need to obtain permission directly from the copyright holder. To view a copy of this licence, visit http://creativecommons.org/licenses/by/4.0/.

(C) The Author(s) 2021 